\title{
James Joyce and the Meanings of Translation
}

\section{Scarlett Baron}

Modernism's deployment of a kaleidoscopic array of languages ranks among its best-known features - a testament to the polyglot erudition of the period's iconic authors and one of the hallmarks of its embrace of difficulty. ${ }^{1}$ If the period deserves, as Stephen Yao suggests in his survey of the many translations undertaken by its canonical writers, to be dubbed 'an age of translations', it is also one in which untranslated fragments assume a marked prominence in literary texts. ${ }^{2}$ Referring to snippets of foreign-language text as instances of non-translation entails thinking about them in a particular light, not merely as moments of accidental oversight but as the mark of a deliberate withholding - whether on the part of author, narrator, persona, or character.

An example of such considered non-translation is clearly at work when, in the third chapter of Woolf's first novel, The Voyage Out, Mr Pepper - a desiccated amateur scholar who is variously likened to 'a vivacious and malicious ape' and 'a fossilized fish in a basin' - impelled by Mrs Dalloway's professed enthusiasm for Sophocles's Antigone, launches into a recitation from the play's second chorus. ${ }^{3}$ Prompted specifically by Mrs Dalloway's impassioned statement that 'I don't know a word of Greek, but I could listen to it for ever -----', Pepper declaims:

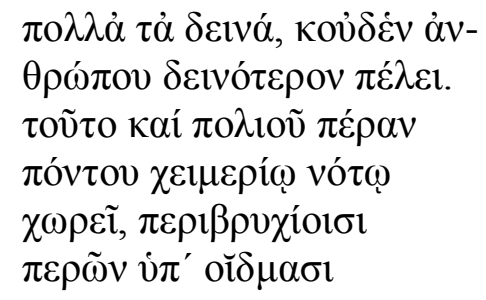

These are lines which many of Woolf's contemporary readers, as well as many late twentieth and early twenty-first century readers, would not have been able to read, their failure replicating the aural bewilderment of Pepper's female audience ('Mrs Dalloway', the laconic narrator observes, 'looked at him with compressed lips.') ${ }^{4}$ And as the ostensible purpose of Pepper's oration is to illustrate the beauty of Greek sounds to an assembly of listeners, readers unable to read Ancient Greek, confronted with illegible signs on a silent white page, have cause to feel doubly left out.

As this example shows, couching an enquiry about foreign-language use in terms of "nontranslation' usefully focuses attention on the motives underpinning the strategic showcasing of other languages in modernist texts. But the hyphenated term presents challenges as well as advantages. The most significant of these concerns its reversibility. That is to say, what is a translation from one point of view may be a non-translation from another. When Joyce attributes incomprehensible words to Eveline's mother in Dubliners - 'Derevaun Seraun!

\footnotetext{
${ }^{1}$ As T.S. Eliot famously declared in 1921, 'poets in our civilization, as it exists at present, must be difficult. - 'The Metaphysical Poets' [1921], Selected Essays (London: Faber and Faber, 1963), 289.

${ }^{2}$ Steven G. Yao, Translation and the Languages of Modernism: Gender, Politics, Language (New York and Basingstoke: Palgrave Macmillan, 2002), 5.

${ }^{3}$ Virginia Woolf, The Voyage Out (Oxford: Oxford University Press, 2001), 12, 14.

${ }^{4}$ Woolf, Voyage Out, 44.
} 
Derevaun Seraun!' - or when Woolf, in Mrs Dalloway, conveys the sound made by the voice of an old woman begging by Regent's Park Tube Station, as

ee um fah um so

foo swee too eem oo

or when, at the end of The Years, she conveys the singing of a chorus of children as

\author{
Etho passo tanno hai \\ Fai donk to tu do, \\ Mai to, kai to, lai to see \\ Toh dom to tuh do -5
}

they are translating sound into combinations of letters, but pointedly not translating the words their characters are seeking to pronounce, refusing to shed light for us on what it is that they are trying to communicate. A similar situation arises in the 'Ithaca' episode of Ulysses when Stephen Dedalus and Leopold Bloom are explicitly said to address each other in Greek or Hebrew, only for their words to be rendered on the page using the letters of the Roman (rather than Greek or Hebrew) alphabet. Are such renderings translations (in the sense that they are at least legible to the reader), non-translations (even in Roman type, the words are still 'all Greek' to many readers, semantically speaking), or half-translations? Such cases, and their profusion within certain key modernist texts, suggest that it may be more accurate to think of the difference between translation and non-translation as a spectrum rather than as a dichotomy a spectrum Joyce's works in particular show him intent on exploring.

\title{
Stephen Hero
}

Translation and non-translation play a significant part in all of Joyce's works, both as a means of characterization and as a vector of political and literary positions. Both already feature prominently in what survives of Stephen Hero, Joyce's draft for A Portrait of the Artist as a Young Man. The highly autobiographical Stephen Daedalus walks the streets of Dublin "with a deliberate unflagging step piecing together meaningless words and phrases with deliberate unflagging seriousness'. ${ }^{6}$ Stephen, like Joyce, has received an extremely thorough training in Latin and been daily exposed to the rituals and Latin liturgy of the Catholic Church. Latinisms - 'patria', 'ex cathedra', 'advocatus diaboli', 'Aula Maxima', 'Alma Mater' - pervade the English he hears around him, blending seamlessly into the fabric of everyday speech $(\mathrm{SH}, 77$, $103,116,171,193)$. Stephen's own use of Latin is formal, scholastic, consisting largely of quotations from philosophers in whose authority he trusts and whose language he deploys in the original with scrupulous accuracy: 'Pulcra sunt quae visa placent', he asserts, quoting Aquinas $(\mathrm{SH}, 95)$. In this, he shows himself to have internalized the prescriptions regarding method and order painstakingly inculcated by his Jesuit education. It is not clear how Stephen himself reconciles his aspirations to be a 'fiery-hearted revolutionary' with a writing style which is 'over affectionate towards the antique and even the obsolete and too easily rhetorical'

\footnotetext{
${ }^{5}$ James Joyce, Dubliners, ed. Jeri Johnson (Oxford: Oxford University Press, 2000), 28; Virginia Woolf, Mrs Dalloway (Oxford: Oxford University Press, 2000), 68-9; Virginia Woolf, The Years (Oxford: Oxford University Press, 1999), 408.

${ }^{6}$ Stephen Hero, ed. Theodore Spencer [1944], revd edn incorporating additional manuscript pages from Yale and Cornell University libraries, ed. John J. Slocum and Herbert Cahoon (New York: New Directions Publishing Corporation, 1963), 31. Further references will be given parenthetically in the text as $S H$.
} 
(SH, 80 and $S H, 27)$. We see him adhere rigorously to a traditional, regimented, and hierarchical view of language and of the world it structures. He follows established forms, and appears to espouse the values they solder. In this, he is not only obviously related to the Stephen of $A$ Portrait of the Artist as a Young Man, who dutifully prefaces his writings with the letters of the Jesuit motto 'A.M.D.G' ('Ad Majoram Dei Gloriam', or 'To the Greater Glory of God'), only signing off below the letters L.D.S. ('Laus Deo Semper', or 'Praise be to God forever'), but also reflects Joyce's own student practice, as the printed version of 'Trust Not Appearances', one of his own student essays (written whilst he was a pupil at Belvedere College between 1893 and 1898), clearly testifies. ${ }^{7}$

As Joyce himself did in 'Trust not Appearances', and as Stephen likewise does in A Portrait of the Artist as a Young Man, the protagonist of Stephen Hero thinks of language in terms of value, and dogmatically prefers old uses to new ones, convinced that words are devalued by translation from one context to another:

Stephen laid down his doctrine very positively and insisted on the importance of what he called the literary tradition. 'Words, he said, have a certain value in the literary tradition and a certain value in the market-place - a debased value.' ( $\mathrm{SH}$, 27)

His sense of the value of words is anchored in his belief in etymology, which offers him a way of finding historical interest in even degraded forms of contemporary parlance:

He read Skeat's Etymological Dictionary by the hour and his mind, which had from the first been only too submissive to the infant sense of wonder, was often hypnotized by the most commonplace conversation. $(\mathrm{SH}, 26)$

The scholarly high-seriousness of Stephen's attitude to language is emphasized by his friends' less reverent approach. Cranly, for instance, takes pleasure in the comedy of linguistic hybridity. Where Stephen is bent on linguistic distinctions, Cranly likes to mix things up, bandying about a sort of proto-Wakean jumble of half-translated languages:

Cranly was speaking (as was his custom when he walked with other gentlemen of leisure) in a language the base of which was Latin and the superstructure of which was composed of Irish, French and German $(\mathrm{SH}, 106)$

Though Stephen takes part in the banter, he does so more reluctantly and laconically:

Cranly at last observed Stephen walking at the edge of the path and said:

- Ecce orator qui in malo humore est.

- Non sum, said Stephen.

- Credo ut estis, said Cranly.

\footnotetext{
${ }^{7}$ A Portrait of the Artist as a Young Man [1916], ed. Jeri Johnson (Oxford: Oxford University Press, 2000) [hereafter abbreviated as P], 58. James Joyce, 'Trust Not Appearances', Occasional, Critical and Political Writing, ed. Kevin Barry (Oxford: Oxford University Press, 2000), 3. The initials make numerous, characteristically distorted returns in Finnegans Wake, for example framing a radio weather forecast as 'Am. Dg' and 'Ls. De.' ( $F W$ 324.23, 325.3), or in intermingled form as 'Ad majorem l.s.d.! Divi gloriam.' ( $F W$ 418.4). Each set of letters in fact receives an entry in Clive Hart's catalogue of recurring Wakean motifs - see Structure and Motif in 'Finnegans Wake' (Evanston, IL: Northwestern University Press, 1962), 213 and 231.
} 
Stephen's linguistic curiosity is not confined to ancient languages. In the course of the novel, he carries out what his father calls 'wayward researches into strange literature' through 'the medium of hardly procured translations' of Ibsen, 'translations of the Hindu and the Greek or Chinese theatres', and 'translations of Turgenieff's novels and stories' (SH, 87, 40, 42). Stephen's attitude to this foreign literature is impassioned: in thrall to Ibsen, he 'suffer[s] the most enduring influence of his life' $(\mathrm{SH}, 40)$. Cranly, by contrast, evinces a derisive selfconsciousness about the use of foreign languages: 'He had a defiant manner of using technical and foreign terms as if he wished to suggest that for him they were mere conventions of language' $(S H, 124)$. To Stephen's acutely sensitive ear, in other words, the effect of this arch delivery is to place such non-translated snippets between aural quotation marks. For all his 'instinctive' affection for Cranly, the trait contributes to his appraisal of his friend as an 'indiscriminate [...] vessel' $(\mathrm{SH}, 124)$. Stephen, by contrast, wants come across as a natural polyglot, at ease with his store of authoritative foreign quotations, in effortless command of his precious cultural capital.

\section{A Portrait of the Artist as a Young Man}

A Portrait opens with an Ovidian epigraph:

Et ignotas animum dimittit in artes.

\section{Ovid, Metamorphoses, VIII, $188 .^{8}$}

Here an instance of paratextual non-translation marks the very threshold of the novel. It is, moreover, an instance of scrupulous quotation (an epigraph, writes Antoine Compagnon, is 'a quotation par excellence') ambiguously poised between the author's and the character's point of view. ${ }^{9}$ Indeed, given what we again come to know in this book about Stephen's proficiency in Latin and his identification with Dedalus, the 'old artificer' he has chosen to regard as his mythical father, the epigraph could well be his, or at least have been chosen as an act of plausible mimicry of his literary tastes and practices $(P, 213)$. The hypothesis that the epigraph is provided as a retrospective extension of the book's dominant mode of free indirect discourse is supported by the fact that it evinces the kind of linguistic and literary purism (i.e. meticulous, attributed, non-translated, quotation) to which we have seen him partial in Stephen Hero ${ }^{10}$ If an epigraph is, as Gérard Genette suggests, 'a password of intellectuality', then the inclusion of such a capsular inscription, and a fortiori of a line excerpted from Ovid, signals the kind of

\footnotetext{
${ }^{8}$ A Portrait of the Artist as a Young Man [1916], ed. Jeri Johnson (Oxford: Oxford University Press, 2000). Further references will be given parenthetically in the text as $P$. The line singled out in Joyce's epigraph is translated as 'So then to unimagined arts he set his mind' in A. D. Melville's translation of the Metamorphoses (Oxford: Oxford University Press, 1986), 177.

${ }^{9}$ Antoine Compagnon, La Seconde Main: ou Le Travail de la citation (Paris: Editions du Seuil, 1979), 337. My translation.

${ }^{10}$ Although the epigraph, as an instance of verbatim quotation, is not a straightforward instance of idiolect-inflected free indirect discourse, it is from a certain perspective assimilable to Hugh Kenner's 'Uncle Charles Principle', which 'entails writing about someone much as that someone would choose to be written about.' The words are Ovid's, not Stephen's - and clearly cited as such - but the fact of quoting from Ovid can be read as part of the book's dominant mode of narration - that is, as a representation of how Stephen might wish his own biography to be framed, or of how he would envisage embarking on his own autobiography. See Hugh Kenner, Joyce's Voices (London: Faber and Faber, 1978), 21.
} 
cultural cachet to which Stephen aspires. ${ }^{11}$ And though Hugh Kenner specifically dismisses as a 'persistent and recurrent fallacy' the critical tendency to suppose that 'the Portrait and Ulysses were written by a Stephen Dedalus', the epigraph itself seems deliberately and ambiguously poised between first- and third-person perspectives. ${ }^{12}$

By cryptically foreshadowing Stephen's surname, the epigraph foregrounds a complex nexus of ideological and political undertones surrounding issues of translation and non-translation. In the section of the Metamorphoses to which Joyce refers, we read - if we can read Greek, that is - of the feats of Daedalos, the Latin name given to the Greek $\Delta \alpha i \delta \alpha \lambda o s$. The epigraph, at once a non-translation and a translation, thus immediately, if subtly, invokes a colonial situation, a cultural appropriation. It enacts the drama of translation as power, as Nietzsche understood it:

And Roman antiquity itself: how forcibly and at the same time how naively it took hold of everything good and lofty of Greek antiquity, which was more ancient! How they translated things into the Roman present! [...] what was past and alien was an embarrassment for them; and being Romans, they saw it as an incentive for a Roman conquest. Indeed, translation was a form of conquest. ${ }^{13}$

Differing readings of Stephen Dedalus's name as a translation - from the Greek ' $\Delta \alpha$ í $\delta \alpha \lambda o \varsigma^{\prime}$, or from the Latin 'Daedalos' - have contending political connotations. 'You have a queer name, Dedalus [...] Your name is like Latin', remarks a fellow pupil of Clongowes in $A$ Portrait $(P, 20)$. Later on, in Chapter IV, his adolescent friends - having discovered that a Greek language and a Greek culture lie behind the Latin and Roman culture in which they are more thoroughly schooled - tease him with punning Greek declensions of his name: 'Stephanos Dedalos! Bous Stephanoumenos! Bous Stephaneforos!' $(P, 142)$

\section{Ulysses: Non-Translated Language}

By the time Stephen appears on the first page of Ulysses, non-translated snippets of Greek and Latin - including his own name - have acquired more defined political implications. Like the epigraph from Ovid that forms the threshold to A Portrait, the Roman, colonial version of Odysseus's name chosen as title of Ulysses - itself a derivation from the Latin 'Ulixes' evokes the analogous subjugation of Ireland to English rule, a subjection manifest in and partly enforced through language, as Stephen had begun to realize in the final chapter of A Portrait. 'The language in which we are speaking', he had reflected in his exchange with the English Dean of Studies, 'is his before it is mine. [...] His language, so familiar and so foreign, will always be for me an acquired speech' $(P, 158)$. Thus Ulysses, like A Portrait, begins by invoking and reenacting an act of linguistic and cultural overwriting.

This thematic undercurrent is further developed in the book's third sentence, in which Buck Mulligan chants the first words of the Catholic Mass: 'Introibo ad altare Dei' or 'I will go up to the altar of $\operatorname{God}^{14}(U 1: 5)$. As Kenner explains, the snippet is a translation as well as non-

${ }^{11}$ Gérard Genette, Paratexts: Thresholds of Interpretation [1987], trans. Jane E. Lewin (Cambridge: Cambridge University Press, 1997), 160.

${ }^{12}$ Hugh Kenner, 'The Portrait in Perspective', The Kenyon Review, Vol. 10, No. 3 (Summer 1948), 361-381, 370.

${ }^{13}$ Friedrich Nietzsche, 'Translation', in The Gay Science [1882], trans. Walter Kaufmann (New York: Vintage, 1974), 136-8; quoted in The Translation Studies Reader, ed. Lawrence Venuti, $2^{\text {nd }}$ ed, 67-8. ${ }^{14}$ James Joyce, Ulysses [1922], ed. Hans Walter Gabler with Wolfhard Steppe and Claus Melchior (New York: Random House, 1986). Parenthetical references will be given in the following form: $U$ episode number: line number. 
translation, being a quotation from St Jerome's Latin version of Hebrew words ascribed to a Psalmist in exile ('Va-a-vo-ah el mizbah elohim'). ${ }^{15}$

Ireland's colonized condition is uppermost in Stephen's mind on the morning of 16 June 1904. With bitterness he tells the Englishman Haines that he is 'the servant of two masters', 'the imperial British state [...] and the holy Roman catholic and apostolic church' ( $U$ 1: 638-644). Stephen's surname, a cause of silent pride and superstitious self-belief in A Portrait, is declared preposterous for its antique flavour:

- The mockery of it! he said gaily. Your absurd name, an ancient Greek! [...]

- My name is absurd too: Malachi Mulligan, two dactyls. But it has a Hellenic ring, hasn't it? (U 1: 34, 41-2).

Although Mulligan pretends to take the sting out of his mockery by deeming his own name absurd as well, Stephen gets the message: apart from being singularly aberrant in turn-of-thecentury Dublin, Stephen's Greek-sounding patronym is the more incongruous because he, unlike Mulligan, knows no Greek (U 1: 77-81).

Mulligan is based on Oliver Gogarty, an Anglo-Irishman educated at Stonyhurst, a Lancashire public school, Trinity College Dublin, and, for two terms immediately preceding his residency in the Martello Tower, at Oxford University. In the course of the eighteenth and nineteenth centuries Greek overtook Latin to become the language of cultural prestige in England. Gogarty studied it, Mulligan speaks it; Joyce did not study it (and minded that he didn't), and Stephen does not speak it. ${ }^{16}$ In the light of this biographical context, and in the light of Mulligan's taunt about Stephen's name, almost all of the non-translated snippets in 'Telemachus' become legible as oblique barbs intended to parade Mulligan's knowledge and emphasize Stephen's ignorance. ${ }^{17}$ Buck coins Homeric epithets, quotes from Homer and Xenophon in transliterated (but not translated) Greek, and even offers Stephen instruction in the language:

- God! he said quietly. Isn't the sea what Algy calls it: a great sweet mother? The snotgreen sea. The scrotumtightening sea. Epi oinopa ponton. Ah, Dedalus, the Greeks! I must teach you. You must read them in the original. Thalatta! Thalatta! She is our great sweet mother. Come and look. (U 1:77-81)

Furthermore, Mulligan's references to Oxford, Matthew Arnold, and Algernon Swinburne ('Algy' in the quotation above) only emphasize the Englishness of his Hellenism - its association, that is, with a colonial perspective. And just as these allusions are not innocent, neither are the allusions to Nietzsche ('I'm the Übermensch. Toothless Kinch and I, the supermen'; 'He who stealeth from the poor lendeth to the Lord. Thus spake Zarathustra'),

\footnotetext{
${ }^{15}$ Hugh Kenner, Ulysses, rev. edn (Baltimore, MD: Johns Hopkins University Press, 1987), 34-5. See also Fritz Senn, Joyce's Dislocutions: Essays on Reading as Translation (Baltimore and London: Johns Hopkins University Press, 1984), 124-5.

${ }^{16}$ Richard Ellmann, James Joyce, revd. edn (Oxford: Oxford University Press, 1982), 118; R.J. Schork, Greek and Hellenic Culture in Joyce (Gainseville: University Press of Florida, 1998), xiii, 239, 245.

${ }^{17}$ As Kenner has noted, the book's first narratorial voice seems to conspire in Buck's Hellenic roleplay: 'Since the Buck is Hellenophile - "Mulligan", as he will soon remark, is a dactyl - the first nine words mimick a Homeric hexameter: "Stately | plump Buck | Mulligan || came from the | stairhead bearing |' - Kenner, Ulysses, 34 [in Kenner's book the quoted words bear scansion marks].
} 
which are particularly striking in the light of his view of translation as conquest $(U 1: 708-9$, 727-8).

Stephen says comparatively little in this episode, and barely any of his utterances comprise those foreign-language snippets to which, as 'Proteus' will show, he is still partial. ${ }^{18} \mathrm{He}$ seems to be silenced by Mulligan's cultural capital, and perhaps also by the realization that his love of Latin - symbolically associated with empire (the Roman Empire), both symbolically and practically associated with the Catholic Church - places him in a position of cultural complicity with his oppressors. As he had already realized in A Portrait, his self-appointed mission 'to forge in the smithy of [his] soul the uncreated conscience of [his] race' requires him to find ways to 'fly by' the 'nets' of 'nationality, language, religion' $(P, 213,171)$.

As well as a new language, Stephen had intuited his need of 'a new personal experience'. ${ }^{19}$ What he likely had in mind (as his musings about creation in terms of reproduction and gestation suggest) is a sexual partner. But the person he meets in Ulysses is Bloom - Irishman, European, Jew, amateur translator. In explaining his introduction of the character of Leopold Bloom, Joyce told his friend Frank Budgen that he was needed because Stephen 'ha[d] a shape that can't be changed' ${ }^{20}$. Yet perhaps Stephen does change a little through his interactions with Bloom, in ways which pertain to language and, specifically, to translation. Stephen is, by inclination, a non-translator; Bloom, in contrast, is by inclination a translator; during their latenight encounter, in friendly compromise, they meet half-way.

Before attending to some of their most telling exchanges, it is worth briefly surveying the linguistic backdrop against which these exchanges take place. There is a great deal of nontranslation in Ulysses. Commentary (especially negative commentary) on this aspect of the text tends to focus on the Stephen-centred episodes: the 'Telemachiad', 'Scylla and Charybdis', in which we return to the mode of scholarly non-translated quotation showcased in the fifth chapter of A Portrait, and the 'Oxen of the Sun' episode, which is full of drunken, boastful, pseudo-intellectual banter. The parading of foreign languages, though potentially alienating to readers of these episodes, is by no means confined to them.

The wealth of such instances of non-translation roughly falls into a few broad categories.

First, the book contains many Latin words relating to church services taking place in Dublin at various times on 16 June 1904, starting with Mulligan's Black Mass atop the Martello Tower and including the words Bloom hears in All Hallows Church in 'Lotus-Eaters', the words he hears at Paddy Dignam's funeral in 'Hades', and the snippets of liturgical Latin wafted over the seaside breeze from the Star of the Sea Church in 'Nausicaa'.

Second, the book is full of Italian musical terms - whether these be the words of songs (the words of Mozart's Don Giovanni or Flotow's Martha for example) $)^{21}$, or words indicating the

\footnotetext{
${ }^{18}$ Stephen's thoughts in 'Proteus' are awash with foreign linguistic material: 'maestro di color che sanno' (U 3: 6-7), 'Nacheinander' (13), 'Nebeneinander' (15), 'lex externa' (48), 'euthanasia' (52), 'aria di sortita' (100), 'Descende, calve, ut ne amplius decalveris' (113-4), 'C'est le pigeon, Joseph' (162), 'mou en civet' (177), Terribilia meditans (311), 'Natürlich' (321), 'frate porcospino' (385), 'diebus ac noctibus iniurias patiens ingemiscit' (466), are just a few among many examples.

19 'When we come to the phenomena of artistic conception, artistic gestation and artistic reproduction I require a new terminology and and new personal experience.' $(P, 176)$.

${ }^{20}$ Frank Budgen, James Joyce and the Making of 'Ulysses' (London: Grayson and Grayson, 1934), 107.

${ }^{21}$ See $U$ 4: 314, $U$ 4: 327-8, $U$ 7: 152, $U$ 18: 1507-8 and $U$ 11: 24, 11: 587, $U$ 11: 594-5, $U$ 16: 1757.
} 
manner of imagined or actual performances ('vibrato', 'piano diminuendo', 'a tempo, strigendo', etc.). ${ }^{22}$

Third, a number of the book's non-translations reflect political intent. The phenomenon is pronounced in 'Telemachus', as discussed earlier in this chapter, but it is also a feature of the 'Cyclops' episode', in which the Citizen's speech features a number of Gaelic locutions ('Slan leat', 'Na bacleis', 'Rameis') (U 12: 819, 12: 884, 12: 1239). His sidekick Lenehan prefers to interject in French, reflecting outdated political sympathies harking back to a time when Ireland had hoped for liberation from the English by the French: 'Conspuez les anglais! Perfide Albion!' (U 12: 1208-09). ${ }^{23}$

Aside from these categories, the vast majority of the non-translated language in Ulysses consists of clichés which bespeak the linguistic aspirations (or, less generously, pretensions) of middle-class Dublin. In 'Aeolus', non-translated snippets of Latin, Greek ('the language of the mind', as MacHugh calls it) ${ }^{24}$, and French swell a tide of journalistic stereotypes, literary flourishes, allusive commonplaces, and conversational bons mots: 'Pardon, monsieur', 'Imperium romanum', 'Cloacae', 'Entrez mes enfants!', 'Domine!', 'Kyrios! [...] Kyrie! [...] Kyrie Eleison!', 'OMNIUM GATHERUM', 'ITALIA, MAGISTRA ARTIUM', 'lex talionis', 'Fuit Ilium!' ${ }^{25}$ In an episode named after the god of wind, nothing emerges so clearly as the assembled journalists' collective determination to give themselves airs. Indeed, while the intention subtending the episode's headlines and dialogue is, transparently, to project an aura of intellectuality, the sheer excess of the pervasive group mannerism backfires, conveying a pretentious affectation diametrically opposed to the impression of spontaneous sophistication the characters would wish to convey.

Such linguistic habits are by no means confined to the newsroom. Dublin at large is awash with this kind of cliché. Simon Dedalus, briefly present in the Freeman's Journal offices before slipping out for a drink with Ned Lambert, betrays the same Aeolian propensity - seemingly typical of the city's shabby-genteel but educated male middle-class - in describing Buck Mulligan, in Virgilian terms, as his son's 'fidus Achates' $(U$ 6: 49). The phrase is reprised in 'Eumeaus', when Bloom, having supplanted Mulligan at Stephen's side, thinks of himself as 'his fidus Achates' ( $U$ 16: 54-5). ${ }^{26}$

Bloom's partiality for foreign phrases, however, is apparent long before 'Eumaeus'. Earlier episodes show him to be eminently prone to use such clichés to frame picture-postcard views of the world around him. In 'Lotus-Eaters', for example, he looks into the window of the Belfast and Oriental Tea Company and daydreams of Ceylon, 'The far east [...] Those Cinghalese lobbing about in the sun in dolce far niente'. 'Esprit de corps', he thinks a little later (perhaps in an unintended pun), remembering how girls help each other protect their bodies from desiring gazes such as his own (U 5: 29-32, 135).

\footnotetext{
${ }^{22} U$ 5: 395; $U$ 9: 905; $U$ 10: 918. See also $U$ 11: 541, $U$ 17: 1309.

${ }^{23}$ Even the citizen has abandoned such illusions: 'The French! says the citizen. Set of dancing masters? Do you know what it is? They were never worth a roasted fart to Ireland.' ( $U$ 12: 1385-6). For more on the history of Franco-Irish relations alluded to in this episode, see Scarlett Baron, 'Strandentwining Cable': Joyce, Flaubert, and Intertextuality (Oxford: Oxford University Press, 2011), 177-191.

${ }^{24} U$ 7: 564 .

${ }^{25} U$ 7: 417, 478, 489, 507, 557, 562-4, 604, 754, 756, 910, 1056.

${ }^{26}$ The assumption here is that the phrase, like the rest of the episode, is an instance of the Uncle Charles Principle (see note 25).
} 
Men are markedly more prone to this kind of linguistic bombast, presumably on account of their access to an education which would have been denied many women (Dilly Dedalus, whom Stephen surprises surreptitiously purchasing a French primer, is a case in point). ${ }^{27}$ In 'Nausicaa', Gerty MacDowell, though sans Latin, has picked up a few phrases from the unwritten dictionary of tasteful foreign phrases. Glamorizing herself, she muses about her own 'innate refinement' and 'languid queenly hauteur'; wonders whether Bloom has 'an aquiline nose or a slightly retroussé'; and reflects on 'the slight contretemps' (the term appears again in the Bloom-inflected narration of 'Eumaeus') occasioned by baby Boardman ( $U$ 13: 97; 13: $420 ; 13: 6124 ; 16: 1880)$. In the context of the episode's flirtation, Bloom likewise reaches for his French, fantasizing about snapshots of '[l]ingerie' and 'deshabille' seen at the mutoscope in Capel Street ( $U$ 13: 796). The connection between Gerty and Bloom is emphasized by their resort, at different points in the same episode, to the very same French word, epitomizing the odd combination of distance and near-immobility which characterizes their sexual encounter: 'Tableau!' (U 13: 486, 815).

In 'Eumaeus', the association between scraps of foreign language and cliché (a reflection of the general tendency of non-translated snippets to congeal into set forms) reaches its high-water mark. Exhausted by his adventures in Nighttown but keen to impress a young companion 'blessed with brains', Bloom's mind (conveyed through free indirect discourse) succeeds only in producing an unwittingly hilarious, carnivalesque unfurling of the English language's tritest foreign imports, a veritable hit parade of turn-of the-century Dublin's dilapidated orts and scraps (many of them repeating appearances in earlier episodes):

à propos, fidus Achates, En route, re, finis, demimonde, confrères, quondam, qui vive, haud ignarus malorum miseris, succurrere disco, etcetera, rara avis, sangfroid, hoi polloi, apropos, protégé, quandary over voglio, Bella Poetria!, Belladonna Voglio, tête-à-tête, post-mortem child, bona fides, tapis, venue, coup d'oeil, stiletto, dénouement, where ignorance is bliss, entre nous, alias, soi-disant, minutiae, paterfamilias, instanter, corruptio per se, corruptio per accidens, in toto, confidante sotte voce, a propos, sine qua non, alias, de rigueur, au fait, crescendo, finale, liaison, ex quibus, Christus, secundum carnem, pro rata, Ubi patria, Alma Mater, vita bene, soi-disant, entourage, prima donna, embonpoint, distinguée, nisi, aplomb, liaisons, quasi, passim, séance, élite, dolce far niente, in medias res, extempore, conversaziones, genus omne, contretemps.

It is this torrent of non-translation, this outpouring of involuntary malapropisms, that led Pound to praise 'Eumaeus' for 'discharging all the clichés of the English language like an uninterrupted river'. ${ }^{28}$ However, Wyndham Lewis - seemingly missing the joke entirely deplored Bloom and Stephen as 'walking clichés' on whom 'a mass of dead stuff is hung'. ${ }^{29}$

${ }^{27}$ Dilly has 'Chardenal's French Primer' in hand when Stephen meets her in 'Wandering Rocks' - $U$ 10: 867-8. The 'Penelope' episode features a smattering of Spanish words, but these come under no suspicion for affectation mainly relating as they do to Molly's memories of a childhood spent in Gibraltar: 'carabineros', 'coronado' (a mistaken substitution for 'coronado' Molly likely intends), 'criada', 'mi fa pieta Masetto [...] presto non son piu forte', 'posadas' ( $U$ 18: 756, 1394, 1483, 1507-8, 1595).

${ }^{28}$ Pound in 'James Joyce et Pécuchet' [1922] in Pound/Joyce: The Letters of Ezra Pound to James Joyce: with Pound's Essays on James Joyce, ed. Forrest Read (London: Faber and Faber, 1968), 200211, 206. My translation.

${ }^{29}$ Wyndham Lewis, 'An Analysis of the Mind of James Joyce', in Time and Western Man [1927], ed. Paul Edwards (Santa Rosa: Black Sparrow Press, 1993), 94 and 100. 
But for all its gaucheness, 'Eumaeus' is not an indictment. It is, instead, as Kenner has argued, an endearing tribute to Bloom, who, having been 'snubbed, thwarted, cuckolded, ignored, jeered at, slandered, put upon', finally feels 'like the hero of a novel, which for Joyce in fiction after fiction is the apotheosis to which fictional beings aspire' ${ }^{30}$ It is also, perhaps primarily, a comic tour de force, in which virtually all of the episode's rambunctious humorous energy derives from the spectacle of style so deftly and comprehensively hoist on its own petard.

\section{Ulysses: Translation and Non-Translation}

In spite of his role in Ulysses as an unintentional vector of cliché, Bloom is at times shown to be attentive to words, alert to their status as snippets of translation or non-translation. One of the first things we see Bloom do, in 'Calypso', is translate:

- Here, she said. What does that mean? [...]

- Metempsychosis, he said, frowning. It's Greek: from the Greek. That means the transmigration of souls.

$-\mathrm{O}$, rocks! she said. Tell us in plain words ( $U$ 4: 337-343).

Bloom has some knowledge of Greek, the educated man's inculcated habit of looking to etymology for meaning, and the ability to articulate a decent definition at a moment's notice. Molly, however wants more: what her husband produces is, in her view, but a half-translation. ${ }^{31}$ Bloom elaborates, translating his own somewhat erudite formulation ('transmigration') into 'plain words':

- Some people believe, he said, that we go on living in another body after death, that we lived before. They call it reincarnation. [...]

- Metempsychosis, he said, is what the ancient Greeks called it. They used to believe you could be changed into an animal or a tree, for instance. What they called nymphs, for example ( $U$ 4:362-3, 375-7).

As Bloom's concatenated explication to Molly shows, knowledge of even one's native language is developed through constant acts of translation (explanatory paraphrase being but the conversion of words into more comprehensible lexical forms). In other words, language acquisition, as this passage reminds us, is itself a process of translation.

In the next episode, 'Lotus-Eaters', Bloom engages in mental translation for his own sake. Having wandered into All Hallows Church, he reflects on the language of the officiating priest. As often, his associative thinking yields to comic associations:

Latin. The next one. Shut your eyes and open your mouth. What? Corpus: body. Corpse. Good idea the Latin. Stupefies them first. [...] Rum idea: eating bits of a corpse why the cannibals cotton to it. (U 5:350)

\footnotetext{
${ }^{30}$ Kenner, Joyce's Voices, 95.

${ }^{31}$ If Molly is dissatisfied with Bloom's first attempt, he later reflects on his wife's faulty translations of foreign linguistic material. Looking back on the events of his day in 'Ithaca', he muses that 'Unusual polysyllables of foreign origins she interpreted phonetically or by false analogy or by both: metempsychosis (met him pike hoses), alias (a mendacious person mentioned in sacred scripture). ( $U$ 17: 685-7)
} 
The passage offers an illustration of the evocative power of non-translated words and phrases, of the way in which locutions imported from other languages, having once 'set' into idiomatic form, become emptied of their semantic meaning, the better suited, by repetition in particular contexts, to bring on a useful passive receptiveness. Bloom's inquisitive mind makes him immune to such 'stupefaction', free to ponder the effectiveness of Latin as a vector of 'rum ideas', a means of cloaking in grandeur arguably outlandish religious practices (in this case, communion and transubstantiation, which Bloom metaphorically aligns with cannibalism).

Bloom brings the same confused half-memories to bear on the priest's cassock:

Letters on his back: I.N.R.I.? No: I.H.S. Molly told me one time I asked her. I have sinned: or no: I have suffered, it is. And the other one? Iron nails ran in ( $U$ 5: 372).

Beyond showing that translation, in the Blooms' household, goes both ways, and beyond providing some fantastically comic lines, Bloom's wild guesses regarding the meaning of the Latin initials ('I.R.N.I.' stands for 'Iesus Nazarenus Rex Iudaeorum', 'I.H.S.' for either 'Jesus Hominum Salvator' or 'In Hoc Signo - Vinces', depending on the authority consulted) illustrate the role of memory in dealing with language that is not immediately understood. ${ }^{32}$ Bloom's various approximate or false translations bring into relief snippets of foreign language which have become largely invisible as non-translated matter, and whose meaning has become effaced through the erosive effect of frequent and largely automatic usage.

In 'Lestrygonians', Bloom tries his hand at some silent musical translation as he walks away from Davy Byrne's, the words his mind focuses on - drawn from Act V, scene 5 of Don Giovanni, in which the libertine meets his comeuppance - reflecting his preoccupation with Molly's approaching tryst with Blazes Boylan:

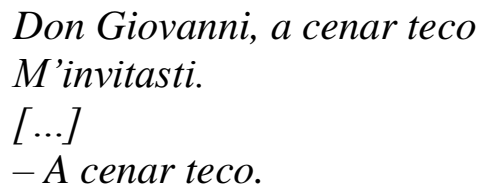

What does that teco mean? Tonight perhaps.

- Don Giovanni, thou hast me invited

To come to supper tonight,

The rum the rumdum ( $U$ 8: 1040-1055).

His attempt, though not resoundingly unsuccessful ('teco' means 'you', not 'tonight', and his improvised verse, as he observes, '[d]oesn't go properly'), and seemingly flavoured by the 'rum ideas' he considered in 'Lotus-Eaters' ('The rum the rumdum'), forms part of his characterization as an inquiring mind, cultured if not erudite, polyglot in aspiration if not in fact ( $U$ 8: 1056).

If Bloom is often to be seen spontaneously engaging in small acts of translation, there are several moments in Ulysses - most notably in 'Circe' - when phrases that have occurred earlier in the book are redeployed in translation, both linguistic and conceptual. When Bloom gives

\footnotetext{
${ }^{32}$ Don Gifford with Robert J. Seidman, Ulysses Annotated: Notes for James Joyce's “Ulysses", revised and expanded edition (Berkeley; London: University of California Press, 1989), 94. The three Latin phrases given here translate into 'Jesus of Nazareth, King of the Jews', 'Jesus the Savior of Man', and 'In this Sign - Thou Shalt Conquer'.
} 
birth to octuplets, for example, the children are named by a process of translation involving the re-use of the two-part structure of 'Chrysostomos', the first word of Stephen's interior monologue in 'Telemachus', and one seemingly suggested by the sight of Mulligan's 'white teeth glistening here and there with gold points' $\left(U\right.$ 1: 25-6). ${ }^{33}$ While 'chryso' is the Latin transliteration of the Greek for 'gold', denoting both the precious metal and its colour, 'stomos' is derived from from the Greek for 'mouth'. Fourteen episodes later, in what is a prime instance of the 'hallucination' technic used in 'Circe', ${ }^{34}$ each of Bloom's children has 'his name printed in legible letters on his shirtfront', and each is based on an analogous combination of a word for a precious metal with a word denoting a body part, gesture, or character trait (nose, finger, hand, smile, self, vivacity, wholeness). The enumeration unfolds in Italian, French, German, and Greek, as well as English: 'Nasodoro, Goldfinger, Chrysostomos, Maindorée, Silversmile, Silberselber, Vifargent, Panargyros' ( $U$ 15: 1823-8).

When Stephen and Bloom spend some time in tête-à-tête in 'Eumaeus' and 'Ithaca', translation is repeatedly foregounded. Stephen sings 'an old German song of Johannes Jeep about the clear sea and the voices of sirens [...] which boggled Bloom a bit', immediately improvising their rendition in English:

\section{Von der Sirenen Listigkeit \\ Tun die Poeten dichten.}

These opening bars he sang and translated extempore. Bloom, nodding, said he perfectly understood and begged him to go on by all means which he did. ( $U$ 16: 1812-9)

Does Bloom really understand perfectly, or has something got lost in translation, as Joyce's use here of the perhaps overly definite adverb comically conspires to suggest? Given what we know of Bloom's affability and his particular keenness to make a good impression on Stephen, it seems quite plausible that his polite over-eagerness might reflect a desire to compensate for his continuing bafflement.

If he does understand 'perfectly', what exactly is it that Bloom understands? It seems reasonable to assume that he hears and grasps the meaning of Stephen's concocted translation (to which the reader is not party) - in which case, does he also deduce the song's connection to the Odyssey $?^{35}$ The German words Stephen intones in his 'phenomenally beautiful tenor voice' are based on a Renaissance Latin translation of the Odyssey entitled 'Dulcia dum loquitur cogitat insidias' ( $U$ 16: 1820). ${ }^{36}$ What Bloom understands, then is subject to the vicissitudes of more than one translation. Stephen's mistaken delivery of 'the end of the ballad' is itself an instance of the distortions texts undergo as they are brought to life by different people in different places and at different times. Jeep's line 'Welches das Schiff in Ungluck bringt' ('Which brings the

\footnotetext{
${ }^{33}$ For a discussion of 'Chrysostomos' and its relation to issues of (linguistic, cultural, narrative, intertextual) translation in Ulysses, see Senn, Joyce's Dislocutions, 138-143.

34 'Circe's 'technic' is named as 'hallucination' in the schema Joyce produced in 1921 to help Stuart Gilbert make sense of Ulysses. The slightly different schema Joyce produced for Carlo Linati in 1920 lists the episode's 'technic' as 'vision animated to bursting point'. Both are reproduced in Jeri Johnson's edition of the 1922 Ulysses (Oxford: Oxford University Press, 1993), on pages 734-5 and 736-9 respectively.

${ }^{35}$ In Gifford and Seidman's translation, the lines read: 'From the Sirens' craftiness | Poets make poems'. (Annotations, 562).

${ }^{36}$ Jeep's song adopts the Latin title as its own (Gifford with Seidman, Annotations, 562).
} 
ship into misfortune') is accidentally altered by Stephen to 'Und alle Schiffe brücken' ('And all ships are bridged'), a meaningless line which even Bloom, for all his alacrity to please and encourage, might struggle to translate into sense $(U 16: 1883-4){ }^{37}$

Perhaps more important than Jeep's song's history of lost and altered meanings, in terms of the overarching human trajectory of Ulysses, is the warmth that Stephen's translation and its reception denote, the promise which the attempt to communicate represents.

In 'Ithaca', Stephen and Bloom's possible friendship is said to face the 'four separating forces' of 'Name, age, race, creed' ( $U$ 17: 402-3). In the course of the discussion that follows this listing, each recites and translates for the other - ancient Irish in Stephen's case, ancient Hebrew in Bloom's:

By Stephen: suil, suil, suil arun, suil go siocair agus suil go cuin (walk, walk, walk your way, walk in safety, walk with care).

By Bloom: kifeloch, harimon rakatejch m'baad l'zamatejch (thy temple amid thy hair is as a slice of pomegranate). (U 17: 727-30)

Here we, like Molly in 'Calypso', are given a literal translation, but the 'plain words' provided in parentheses don't exactly make for full enlightenment as regards the meaning of the fragments each man recites. Most readers would probably require further explication in order to make sense of the words. As in the example of Jeep's song, the exchange, by withholding information, highlights the limitations of literal translation, showing how insufficient are wordto-word approximations to the restitution of meaning.

Not content merely to compare the sound of the ancient languages associated with their respective races, the two protagonists proceed to a 'glyphic comparison of the phonic symbols of both languages':

Stephen wrote the Irish characters for gee, eh, dee, em, simple and modified, and Bloom in turn wrote the Hebrew characters ghimel, aleph, daleth and (in the absence of mem) a substituted qoph, explaining their arithmetical values as ordinal and cardinal numbers, videlicet $3,1,4$, and 100. (U 17:736-40)

As they trace loops and scriptural arabesques on the sheet before them, the reader is, once again, and quite literally this time, left out of the loop. We see Roman-literal translations of the Irish and Hebrew characters in question but remain none the wiser as to how they look on the page or sound when spoken. Our experience of these signs, in other words, is the obverse of Stephen and Bloom's auditory and visual apprehensions.

Critical commentary regarding this description of Stephen and Bloom's scribblings evinces a degree of perplexity about Joyce's choice of characters. Tim Conley rightly observes that 'One of the fascinating elements in this scene is the "absence of mem." He suggests one possible explanation:

\footnotetext{
${ }^{37}$ Gifford with Seidman, Annotations, 562.
} 
Bloom, who has already shown himself on various occasions to be lax in observing his Judaism, may be making a mistake in his Hebrew alphabet. Bad handwriting

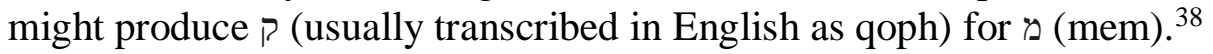

Schork, in contrast, hypothesizes that the letters, instead of appearing as the result of a failure of memory, are in fact produced by Bloom in accordance with a mnemotechnic aid for the mental retention of the first numbers of pi $(\pi), 3.14$ :

The parenthetical phrase 'in the absence of mem' serves a twofold function. First, it calls explicit attention to the fact that the final Hebrew letter ('goph') in Bloom's transcription is not a phonetic parallel to Stephen's Gaelic character 'em', which might seem to call for a symmetrical response of 'mem' (the $13^{\text {th }}$ letter of the Hebrew alphabet $=\mathrm{M})$. Second, it is a clue to the source of Bloom's inscription: the recollection of a childhood prop for his notoriously shaky memory. ${ }^{39}$

The equivalence works, claims Schork, because 'qoph', which stands for 100, is to be understood not as representing 'the cardinal number' but rather as 'a reminder that the previous digits are to be marked with a decimal point', as in ' $3.14 '{ }^{40}$ On this interpretation, the fact that Stephen's characters do not 'translate' into Bloom's is counterbalanced by the introduction of a new kind of translation, of letters into numbers - one to be added to the catalogue of types of translation Ulysses explores. Whether many readers are in position to 'perfectly understand' so abstruse a demonstration, however, is open to question.

Bloom and Stephen next go on to search for 'points of contact [...] between these languages and between the peoples who spoke them', including 'diacritic aspirations', 'servile letters' (the adjectives punningly translating into political as well as graphic meanings), 'antiquity', common descent from Noah, literary, historical, and religious convergences, 'dispersal, persecution, survival and revival', hopes of 'restoration' and 'political autonomy' ( $U$ 17: 74560). Bloom seemingly celebrates these parallels and intersections by chanting a Hebrew anthem

Kolod balejwaw pnimah

Nefesch, jehudi, homijah.

- but has to stop after the first two lines 'in consequence of defective mnemotechnic'. Instead, Bloom gives Stephen 'a periphrastic version of the general text' $(U$ 17: 763-4, 766, 768). We, however, are not party to this - nor are we told whether Stephen 'perfectly understood'.

Finally, the two make a 'common study' and formulate 'mutual reflections' on the subject of the Egyptian, Greek, Roman, Semitic, Celtic alphabets, stenography, and the telegraphic code, and Stephen, an aspiring reader of signatures ('Signatures of all things I am here to read)' whose name has been variously pondered, declined, and derided, 'appends his signature in Irish and Roman characters' ( $U$ 3: 2; $U$ 17: 769-75).

\footnotetext{
${ }^{38}$ Tim Conley, Joyces Mistakes: Problems of Intention, Irony, and Interpretation (Toronto and London: University of Toronto Press, 2003), 73.

${ }^{39}$ R. J. Schork, 'A Graphic Exercise of Mnemotechnic', James Joyce Quarterly, 16:3 (Spring, 1979), 351-354, 353. See also R.J. Schork, Latin and Roman Culture in Joyce (Gainesville: University Press of Florida, 1997), 22, 24, 255n12. The 'goph' featured in Schork's quotation (published in 1979) is accurate to the text of the 1922 Ulysses - the Gabler edition (1984) amended 'goph' to 'qoph'.

${ }^{40}$ Schork, 'A Graphic Exercise', 352.
} 
What, if anything, can be concluded from the myriad instances of translation and nontranslation showcased in Ulysses, and Joyce's placement, at its centre, of Leopold Bloom, a translator by inclination if not in terms of linguistic proficiency? To hazard conclusions on the basis of a partial survey of so vast a range of instances is to risk the kind of egregious simplifications which the very profusion of Joyce's writing seems designed to invalidate. With that caveat acknowledged, one might, for the sake of a synoptic overview, propose two types of inference: pragmatic on the one hand, theoretical on the other. If, as Fritz Senn points out, Ulysses shows that we are often at risk of being 'locked into our own little cognitive systems' and that 'in certain constellations' we are all 'aliens and fumbling outsiders' ${ }^{41}$ translation and the goodwill it can foster among individuals and nations are all the more important. Stephen and Bloom do seem to be getting somewhere in their relationship when they translate for each other, compare the scripts and sounds of ancient languages, and unearth connections between their linguistic and ethnic identities. On a more abstract, theoretical level, the remarkable linguistic diversity of Ulysses illustrates the multiplicity and inextricability of semiotic systems. As Joyce notes in 'Ireland: Island of Saints and Sages', 'What race or language can nowadays claim to be pure?' 42 Even ostensibly non-translated language, like Mulligan's opening chant in 'Telemachus', or Stephen's singing of Jeep, has typically been through countless translations before assuming the form in which we encounter it. Considered closely, the plethora of non-translated orts and scraps in Ulysses points to the fact that all nontranslation is itself translation, and that no translation is really a full translation. In this intimation, it looks forward to the wildly polyglot, ceaselessly 'transluding' world of Finnegans Wake - a text in which virtually all words seem to bespeak their status as elements in a translation in progress. ${ }^{43}$

\footnotetext{
${ }^{41}$ Senn, Joyce's Dislocutions, 59 and 53.

${ }^{42}$ James Joyce, 'Ireland: Island of Saints and Sages' [1907], in Joyce, Occasional, Critical, and Political Writing, 118.

${ }^{43}$ James Joyce, Finnegans Wake [1939] (London: Faber and Faber, 1975), 419 (line 24).
} 